\title{
RETROSPECTIVE COMPARISON OF CD34-SELECTED ALLOGENEIC PERIPHERAL BLOOD STEM CELL TRANSPLANTATION FOLLOWED BY CD8-DEPLETED DONOR LYMPHOCYTE INFUSIONS WITH UNMANIPULATED BONE MARROW TRANSPLANTATION
}

Running tittle: CD34-selected PBSCT plus CD8-depleted DLI versus unmanipulated BMT

Frédéric Baron, Etienne Baudoux, Georges Fillet and Yves Beguin.

Department of Medicine, Division of Hematology; University of Liège, Liège, Belgium.

Frédéric Baron is Senior Research Assistant and Yves Beguin Research Director of the National Fund for Scientific Research (FNRS, Belgium). This work was supported by grants from "La Fondation Bonjean-Oleffe", "Le Fonds de Recherche Scientifique du CHU SartTilman" and "the National Fund for Scientific Research (FNRS, Belgium)".

$\underline{\text { Address for correspondence: }}$

\author{
Yves Beguin, MD \\ University of Liège \\ Department of Hematology \\ CHU Sart-Tilman \\ 4000 Liège \\ Belgium \\ Tel +32 - 4 - 3667201 \\ Fax +32 - 4 - 3668855 \\ E-mail: yves.beguin@chu.ulg.ac.be
}




\begin{abstract}
We have previously reported the feasibility of allogeneic CD34-selected PBSC transplantation followed by pre-emptive CD8-depleted DLI (study group). In this report, we retrospectively compare the clinical outcome of the 24 patients included in this study with an historical group of 35 patients receiving unmanipulated marrow (BMT group). Patients in the study group had significantly faster neutrophil and platelet recovery and were discharged earlier than BMT patients. The actuarial 150-day (after DLI) probability of developing grade IIIV acute GVHD was $28 \%$ for the study group versus $62 \%$ for the BMT group ( $\mathrm{p}=0.002$ ). The actuarial 2-yr probability of developing chronic GVHD was similar (37\% versus $36 \%$ (NS)) but chronic GVHD was significantly delayed in the study group $(\mathrm{p}=0.003)$. The actuarial 2-yr probability of relapse was $30 \%$ in the study group versus $33 \%$ in the BMT group (NS). The actuarial 2-yr probability of survival was $45 \%$ in the study group versus $43 \%$ in the BMT group (NS). We conclude that allogeneic transplantation of CD34-selected PBSC followed by preemptive CD8-depleted DLI is feasible with rapid engraftment and minimizes the risk of severe GVHD. Large prospective trials are required to confirm these results.
\end{abstract}

Key words: Allogeneic transplantation, GVHD, GVL, CD34 selection, donor lymphocyte infusions. 


\section{INTRODUCTION}

Graft-versus-host host disease (GVHD) is a life-threatening complication of allogeneic hematopoietic stem cell transplantation $(\mathrm{HSCT})^{1 ; 2}$. It is due to donor lymphocytes cotransplanted with donor stem cells that are primed by histocompatibility differences between donors and recipients and activated by a cytokine storm caused by the conditioning regimen ${ }^{3}$. The most efficient method for prevention of GVHD consists in T-cell depletion (TCD) of the graft $^{4 ; 5}$. However, this usually leads to an increased risk of leukemia relapse because of the loss of the graft-versus-leukemia (GVL) effect ${ }^{6-8}$. To lessen the impact of TCD on leukemia relapse, several groups have studied the feasibility of preemptive donor lymphocyte infusion (DLI) given several weeks to months after the transplant, i.e. after the cytokine storm and after the patient has recovered from conditioning-regimen related toxicities ${ }^{9-16}$. Two of them have shown that pre-emptive DLI induced a strong GVL effect ${ }^{13 ; 14}$ but it remains to be demonstrated whether this strategy effectively decreases the incidence of GVHD.

Previous studies have demonstrated that it is possible to maintain a GVL effect without GVHD by CD8-depletion of DLI given for leukemic relapse after BMT ${ }^{17-19}$. Therefore, we have recently developed an original strategy of pre-emptive infusions of CD8-depleted donor lymphocytes given in incremental doses after CD34-selected peripheral blood stem cell transplantation (PBSCT) ${ }^{16}$. In this article, we retrospectively compare the clinical outcome of the 24 patients included in this study with an historical group of 35 patients receiving unmanipulated marrow (BMT group) for similar hematological malignancies. 


\section{PATIENTS AND METHODS}

\section{Patients and donors}

Twenty-four patients with hematologic malignancies, 18 males and 6 females, aged 14 to $56 \mathrm{yrs}$ (median $46 \mathrm{yrs}$ ) were included in the study group. Twelve patients (7 AML, 2 ALL and 1 NHL in first remission and 2 CML in first chronic phase) were designated as standard risk for relapse although 4 had poor prognostic cytogenetic abnormalities. The remaining 12 patients with more advanced disease were considered as high risk, including an ALL patient in first CR because of the very high number of lymphoblasts and massive cerebral leucostasis at diagnosis. Transplants were carried out from matched $(\mathrm{N}=16)$ or one-mismatch $(\mathrm{N}=8)$ related donors (table 1). Written informed consent was obtained from patients and donors and our institution's Ethical Committee approved the protocol. Results were compared with an historical group including all patients transplanted after 1991 with unmanipulated allogeneic bone marrow from related donors for diseases also included in the study group (BMT group, $\mathrm{N}=35$ ) (table 1). Twenty patients (12 AML and 4 ALL in first remission and 4 CML in first chronic phase) were considered as standard risk. The remaining 15 patients with more advanced disease were considered as high risk.

\section{Clinical management}

Hematopoietic stem cells were infused on day 0 through a Hickman catheter after a TBI-based or busulfan-based conditioning regimen. All patients in the study group (versus only 13 in the BMT group, $\mathrm{p}<0.001)$ were treated with $5 \mu \mathrm{g} / \mathrm{kg} / \mathrm{d}$ lenogastrim $\left(\right.$ Granocyte $^{\circledR}$ ) from day +1 until the granulocyte count was $\geq 10^{9} / \mathrm{L}$ for three consecutive days or $\geq 10^{10} / \mathrm{L}$ for one day. Six of the first 9 patients in the study group (4 not HLA-identical to their donor and 2 AML in CR1) received short methotrexate in addition to cyclosporine. Because of the low 
incidence of acute GVHD observed in the first 9 patients, GVHD prophylaxis was carried out with CyA alone for patients 10 to 24. A smaller proportion $(11 / 35, \mathrm{p}<0.001)$ of the patients in the BMT group received CyA alone as GVHD prophylaxis because of their young age and high risk of post-transplant relapse. The diagnosis and grading of acute and chronic GVHD was established as previously reported ${ }^{20 ; 21 ; 21}$. Disease evaluation, including bone marrow aspirations and biopsies were routinely carried out on days 40, 100, 180 and 365.

\section{Stem cell and lymphocyte collection, selection and infusion}

Bone marrows were collected from the posterior iliac crest under general anesthesia and infused unmanipulated into recipients on the day of harvest. In case of minor and/or major ABO incompatibility, plasma and/or RBC were removed before infusion. For PBSC collections, donors received human G-CSF (Granocyte ${ }^{\circledR}$, kindly provided by Rhone-PoulencRoerer, Brussels, Belgium) at 10-15 $\mu \mathrm{g} / \mathrm{kg}$ from day -5 through day -1 . PBSC were collected on days -1 and 0 , pooled, and CD34-selected using the Isolex $300 i^{\odot}$ magnetic cell separator (Baxter-Fenwall Laboratories, Deerfield, IL), as previously reported ${ }^{16 ; 22}$.

Around day 60 post-PBSCT, donor lymphocytes were collected on 2 consecutive days, pooled and submitted to CD8-selection using the Nexell Isolex $300 \mathrm{i}^{\circledR}$, as previously described $^{16}$. The CD8-negative fraction was recovered and divided into 3 aliquots containing 2 $\mathrm{x} 10^{6}, 1 \times 10^{7}$ and $5 \times 10^{7} \mathrm{CD}^{+}$cells $/ \mathrm{kg}$ recipient for patients 1 to 13 or into 2 aliquots of $1 \mathrm{x}$ $10^{7}$ and $5 \times 10^{7} \mathrm{CD}^{+}$cells/kg recipient for patients 14 to 21 . Aliquot 1 was injected fresh immediately after the CD8 depletion procedure (around day 60). Around day 100 (and 140 for patients 1 to 13 ), cryopreserved aliquots 2 (and 3) were thawed and infused into the patient. CD8-depleted DLI were not to be infused in case of an antecedent grade III or IV acute GVHD, or an antecedent of extensive chronic GVHD, or active GVHD at time of scheduled infusion. 
Statistical analyses

The probability of GVHD, relapse, and survival as well as the speed of engraftment were studied by life-table analyses and Wilcoxon rank tests were used for comparisons between groups. Statistical analyses were carried out with Graphpad Prism (Graphpad Software, San Diego, CA). 


\section{RESULTS}

\section{Engraftment kinetics}

The median time to achieve an absolute neutrophil count of $0.5 \times 10^{9} / \mathrm{L}$ was 11 days for the study group versus 22 days in the BMT group ( $\mathrm{p}<0.001)$ (Figure 1A). Median times to $20 \mathrm{x}$ $10^{9} / \mathrm{L}$ platelets were 13 versus 24 days $(\mathrm{p}=0.004$ ) (Figure $1 \mathrm{~B})$ and median times to $1 \%$ reticulocytes 17 versus 25 days ( $\mathrm{p}=0.005)$ (Figure $1 \mathrm{C})$. Median time to hospital discharge was 21 days for the study group versus 36 days for the BMT group ( $\mathrm{p}=0.010$ ) (Figure 1D).

\section{Graft-versus-host disease}

The study group had a higher proportion of patients over the age of 40 (63\% vs $37 \%$, $\mathrm{p}=0.055)$ and a higher proportion of mismatched transplants (33\% versus $14 \%, \mathrm{p}=0.082)$, and thus a larger proportion of patients at high risk of GVHD (75\% vs 43\%, p=0.015). Furthermore, the study group had more frequent omission of MTX as part of the GVHD prophylaxis (75\% versus $31 \%, \mathrm{p}<0.001$ ). Therefore, the study group was considered at higher risk of GVHD (at least one of these 3 factors present) than the BMT group ( $\mathrm{p}=0.010)$.

Twenty-six of the 35 patients in the BMT group developed acute GVHD (6 grade I, 9 grade II, 8 grade III and 3 grade IV) compared with 14/24 patients in the study group ( 9 grade I, 5 grade II and 1 grade IV). Before DLI, the actuarial 60 days incidence of grade II-IV acute GVHD was $17 \%$ for the study group versus $62 \%$ for the BMT group $(\mathrm{p}<0.001)$. After DLI, the actuarial 150-day probability of developing grade II-IV acute GVHD was $28 \%$ for the study group versus $62 \%$ for the BMT group ( $\mathrm{p}=0.002$ ) (Figure 2A). For HLA-identical sibling transplant recipients, the figures were $13 \%$ versus $55 \%(\mathrm{p}=0.006)$.

The actuarial 2-yr probability of developing chronic GVHD was similar (37\% versus $36 \%$ (NS)) but chronic GVHD was significantly delayed in the study group ( $\mathrm{p}=0.003$ ) (figure 
2B). For HLA-identical sibling transplant recipients, the figures were $12 \%$ in the study group versus $33 \%$ in the BMT group ( $\mathrm{p}=0.16$ ). Among at-risk patients (surviving beyond day 100), the incidence of extensive chronic GVHD was lower in the study group (1/18 or $6 \%$ vs $9 / 26$ or $35 \%, \mathrm{p}=0.024)$. Their actuarial 2 -yr rates were $13 \%$ and $36 \%$, respectively $(\mathrm{p}=0.031)$. For HLA-identical siblings, the figures were $0 \%(0 / 11)$ in the study group versus $32 \%$ in the BMT group $(7 / 22)(\mathrm{p}=0.035)$. The actuarial 2 -yr rates were $0 \%$ and $33 \%$, respectively $(\mathrm{p}=0.06)$.

Relapse, transplant-related mortality and overall survival

The actuarial 2-yr probability of relapse was $30 \%$ in the study group versus $33 \%$ in the BMT group (NS) (Figure 3A). For malignancies other than ALL, the figures were $14 \%$ and $37 \%$, respectively $(\mathrm{p}=0.2)$. Three of 5 ALL patients in the study group versus none of 7 in the BMT group relapsed $(\mathrm{p}=0.055)$. This could be partially explained by the occurrence of grade IIIV GVHD in $1 / 5$ patients in the study group versus 5/7 in the BMT group.

Non-relapse causes of death were multiple organ failure $(\mathrm{N}=2)$, sudden death at home $(\mathrm{N}=2), \operatorname{GVHD}(\mathrm{N}=1)$, interstitial pneumonia $(\mathrm{N}=1)$, veno-occlusive disease of the liver $(\mathrm{N}=1)$ and toxic hepatic failure $(\mathrm{N}=1)$ in the study group and GVHD $(\mathrm{N}=5)$, interstitial pneumonia $(\mathrm{N}=3)$, veno-occlusive disease of the liver $(\mathrm{N}=1)$ and multiple organ failure $(\mathrm{N}=1)$ in the BMT group. The actuarial 1-yr probability of transplant-related mortality was $34 \%$ in the study group versus $33 \%$ in the BMT group.

The actuarial 2 -yr probability of survival was $45 \%$ in the study group versus $43 \%$ in the BMT group (NS) (Figure 3B). For standard risk patients, disease-free survival was $64 \%$ in the study group versus 55\% in the BMT group (NS). For high-risk patients the figures were 18\% and $27 \%$, respectively (NS). 


\section{DISCUSSION}

Several reports have demonstrated that hematologic recovery was faster after PBSC transplantation compared with $\mathrm{BMT}^{23-25}$. In our study, neutrophil, erythrocyte and platelet engraftments were significantly faster in the study than in the BMT group, although faster neutrophil engraftment could be partly due to more common use of G-CSF in the study group. This faster hematologic recovery permitted to discharge study group patients significantly faster than patients of the BMT group.

As previously suggested by others ${ }^{26}$, our results show that CD34-selection reduces the risk of acute GVHD. The actuarial 60-day (before DLI) probability of grade II-IV acute GVHD was $17 \%$ in our study. This rate compares very favorably with our historical BMT group (62\%, $\mathrm{p}<0.001)$ and with studies of HLA-identical siblings receiving unmanipulated PBSC or $\mathrm{BM}^{24 ; 25}$. For example in the most recent report of the Seattle group ${ }^{25}$, the 100 -day incidence of grade II-IV acute GVHD was 64\% in the PBSC group and 57\% in the BM group. Our 55\% rate of acute GVHD in HLA-identical siblings undergoing BMT (including the one third of our BMT patients who did not receive short MTX) is comparable to the $57 \%$ incidence reported recently by the Seattle group with cyclosporine and short methotrexate ${ }^{25}$. In addition, the occurrence of chronic GVHD was considerably delayed compared to BMT recipients (Figure 2), indicating that it occurred more as a result of DLI rather than of the CD34-selected graft. This took place despite the higher proportion of mismatched transplants and older patients in our study group as well as the lower use of MTX in addition to CyA for GVHD prophylaxis.

Recent evidence implicates a preparative regimen-related "cytokine storm" in the pathogenesis of acute GVHD following $\mathrm{HSCT}^{1 ; 3}$. Therefore, delaying the infusion of donor lymphocytes after this storm has subsided could result in a lower risk of acute GVHD ${ }^{27}$. The feasibility of T-cell depletion of the graft followed by preemptive DLI was first demonstrated by the Jerusalem's group ${ }^{9}$. Since them, several other studies have also investigated the infusion 
of $\mathrm{T}$ cells, a few weeks to a few months after T-cell depleted transplantation ${ }^{10-16}$. However, although the final goal of these approaches is to decrease the risk of graft-versus-host disease without compromising the GVL effect, none of them has compared the incidence of GVHD after TCD HSCT followed by pre-emptive DLI with a cohort of patients receiving unmanipulated HSCT. In our study group, 19/24 patients received pre-emptive CD8-depleted DLI and DLI were never withheld because of GVHD. These DLI were very well tolerated in patients 1-13 (only 4 patients developed grade II acute GVHD) leading us to omit short MTX even in mismatched or older patients and then to infuse higher doses of CD8-depleted donor lymphocytes earlier in patients 13-24. These doses again did not induce any severe acute GVHD except in patient 21 who developed grade IV acute GVHD and died of infection and GVHD. Although low doses of $\mathrm{CD}^{+}$cells were infused because the degree of $\mathrm{CD} 8^{+}$cell depletion was moderate (only $1.5 \mathrm{log}$ ) and although we injected more $\mathrm{CD} 4^{+}$cells because the total dose of T cells was maintained at $5 \times 10^{7} / \mathrm{kg}$, the procedure was efficient to prevent severe GVHD. Compared with our historical BMT group, the probabilities of grade II-IV acute GVHD and of extensive chronic GVHD were significantly lower. This was achieved despite the higher proportion of mismatched and older transplant recipients, resulting in a higher theoretical risk of developing severe GVHD. For HLA-identical sibling transplants, the incidence of grade II-IV acute GVHD, chronic GVHD and extensive chronic GVHD were $13 \%, 12 \%$ and $0 \%$, respectively. These incidences are lower than previously reported in HLAidentical BMT with MTX and CyA as GVHD prophylaxis ${ }^{28}$ and even more so in HLAidentical PBSCT ${ }^{24: 25}$. Therefore, our results show that it is possible to circumvent GVHD by delaying the addition of donor lymphocytes after CD34-selected transplantation.

The mechanisms and specificity of the GVL reaction remain uncertain ${ }^{7 ; 29}$. Although the contribution of $\mathrm{CD}^{+} \mathrm{T}$ cells cannot be dismissed, $\mathrm{CD} 4^{+} \mathrm{T}$ cells are believed to be the primary mediators of $\mathrm{GVL}^{18 ; 30}$. Therefore, pre-emptive infusion of large doses of CD4+ (and NK) cells 
in our study should be expected to preserve the GVL effect. Indeed, the relapse rate was comparable to that of our historical BMT group, although obviously both groups were quite heterogeneous for initial diagnosis and clinical status before transplant. The relapse rate was also much lower than previously described after $\mathrm{T}$ cell depleted transplantation ${ }^{31}$. We observed no relapse in the standard risk patients and only 50\% relapses in the high-risk patients. Interestingly, whereas previous studies have shown that the persistence of BCR-ABL transcripts after TCD BMT strongly predicted for relapse, recurrence of CML could be prevented by DLI in one such patient ${ }^{16}$. More ALL patients in the study group relapsed compared to the BMT group. This finding could be partially explained by the lower occurrence of grade II-IV GVHD in the study group. It is well demonstrated that the risk of relapse is much lower in ALL patients who developed grade II-IV acute GVHD but paradoxically is not affected by T-cell depletion of the graft ${ }^{32}$. Thus, it is possible that a strategy to separate the GVL effect from GVHD may not be successful in ALL patients.

We conclude that allogeneic CD34-selected PBSCT followed by pre-emptive CD8depleted DLI appears to be a promising strategy to separate the GVL effect from GVHD. CD34-selection of the graft and CD8-depletion of DLI resulted in substantial benefits for the patients in terms of acute and chronic GVHD despite the large proportion of HLA mismatches. The use of pre-emptive DLI appeared to maintain the GVL effect in a high-risk population but this remains to be demonstrated in more homogenous groups of patients. Large randomized studies are needed to determine whether this strategy could improve overall survival as well as the quality of life of the patients. 


\section{Reference List}

1. Ferrara JL, Levy R, Chao NJ: Pathophysiologic mechanisms of acute graft-versus-host disease. Biol Blood Marrow Transplant 5: 347-356, 1999

2. Goerner M, Gooley T, Flowers ED, Sullivan KM, Kiem HP, Sanders J, Martin PJ, Storb R: Morbidity and mortality of chronic GVHD after hematopoietic stem cell transplantation from HLA-identical siblings for patients with aplastic or refractory anemias. Biol Blood Marrow Transplant 8: 47-56, 2002

3. Ferrara JL: Pathogenesis of acute graft-versus-host disease: cytokines and cellular effectors. J.Hematother.Stem Cell Res. 9: 299-306, 2000

4. Drobyski WR: Evolving strategies to address adverse transplant outcomes associated with T cell depletion. J.Hematother.Stem Cell Res. 9: 327-337, 2000

5. Ho VT, Soiffer RJ: The history and future of T-cell depletion as graft-versus-host disease prophylaxis for allogeneic hematopoietic stem cell transplantation. Blood 98: 3192-3204, 2001

6. Baron F, Beguin Y: Adoptive immunotherapy with donor lymphocyte infusions after allogeneic HPC transplantation. Transfusion 40: 468-476, 2000

7. Barrett J, Childs R: The benefits of an alloresponse: graft-versus-tumor. J.Hematother.Stem Cell Res. 9: $347-354,2000$

8. Slavin S, Morecki S, Weiss L, Or R: Donor lymphocyte infusion: the use of alloreactive and tumor-reactive lymphocytes for immunotherapy of malignant and nonmalignant diseases in conjunction with allogeneic stem cell transplantation. J Hematother.Stem Cell Res. 11: 265-276, 2002

9. Naparstek E, Or R, Nagler A, Cividalli G, Engelhard D, Aker M, Gimon, Manny N, Sacks T, Tochner Z: Tcell-depleted allogeneic bone marrow transplantation for acute leukaemia using Campath-1 antibodies and post-transplant administration of donor's peripheral blood lymphocytes for prevention of relapse. Brit J Haematol 89: 506-515, 1995

10. Barrett AJ, Mavroudis D, Tisdale J, Read E: T cell-depleted bone marrow transplantation and delayed T cell add-back to control acute GVHD and conserve a graft-versus-leukemia effect. Bone Marrow Transplant 21: $543-551,1998$ 
11. Lee CK, Gingrich RD, deMagalhaes-Silverman M, Hohl RJ, Joyce JK, Scott SD, Wen BC, Schlueter A: Prophylactic reinfusion of T cells for T cell-depleted allogeneic bone marrow transplantation. Biol.Blood Marrow Transplant. 5: 15-27, 1999

12. Martino R, Martin-Henao G, Sureda A, Altes A, Canals C, Brunet S, Sierra J: Allogeneic peripheral blood stem cell transplantation with CD34-cell selection and delayed T-cell add-back in adults. Results of a single center pilot study. Haematologica 85: 1165-1171, 2000

13. Alyea EP, Weller E, Schlossman R, Canning C, Webb I, Doss D, Mauch P, Marcus K, Fisher D, Freeman A, Parikh B, Gribben JG, Soiffer RJ: T-cell-depleted allogeneic bone marrow transplantation followed by donor lymphocyte infusion in patients with multiple myeloma: induction of graft-versus-myeloma effect. Blood 98: 934-939, 2001

14. Schaap N, Schattenberg A, Bar B, Preijers F, van de Wiel van Kemenade, De Witte T: Induction of graftversus-leukemia to prevent relapse after partially lymphocyte-depleted allogeneic bone marrow transplantation by pre- emptive donor leukocyte infusions. Leukemia 15: 1339-1346, 2001

15. Nakamura R, Bahceci E, Read EJ, Leitman SF, Carter CS, Childs R, Dunbar CE, Gress R, Altemus R, Young NS, Barrett AJ: Transplant dose of CD34(+) and CD3(+) cells predicts outcome in patients with haematological malignancies undergoing $\mathrm{T}$ cell-depleted peripheral blood stem cell transplants with delayed donor lymphocyte add-back. Br.J Haematol 115: 95-104, 2001

16. Baron F, Siquet J, Schaaf-Lafontaine N, Baudoux E, Hermanne JP, Fillet G, Beguin Y: Pre-emptive immunotherapy with CD8-depleted donor lymphocytes after CD34-selected allogeneic peripheral blood stem cell transplantation. Haematologica 87: 78-88, 2002

17. Giralt S, Hester J, Huh Y, Champlin R: CD8-depleted donor lymphocyte infusion as treatment for relapsed chronic myelogenous leukemia after allogeneic bone marrow transplantation. Blood 86: 4337-4343, 1995

18. Alyea EP, Soiffer RJ, Canning C, Ritz J: Toxicity and efficacy of defined doses of CD4+ donor lymphocytes for treatment of relapse after allogeneic bone marrow transplant. Blood 91: 3671-3680, 1998

19. Shimoni A, Gajewski JA, Donato M, Martin T, O'Brien S, Talpaz M, Cohen A, Korbling M, Champlin R, Giralt S: Long-Term follow-up of recipients of CD8-depleted donor lymphocyte infusions for the treatment 
of chronic myelogenous leukemia relapsing after allogeneic progenitor cell transplantation. Biol Blood Marrow Transplant 7: 568-575, 2001

20. Przepiorka D, Weisdorf D, Martin P, Klingemann HG, Beatty P, Hows J, Thomas ED: 1994 Consensus Conference on Acute GVHD Grading. Bone Marrow Transplant. 15: 825-828, 1995

21. Margolis J, Vogelsang G: Chronic graft-versus-host disease. J.Hematother.Stem Cell Res. 9: 339-346, 2000

22. Baron F, Baudoux E, Frère P, Tourqui S, Schaaf-Lafontaine N, Greimers R, Herens C, Fillet G, Beguin Y: Nonmyeloablative stem cell transplantation (NMSCT) with CD8-depleted or CD34-selected PBSC. J Hematother Stem Cell Res. 11: 301-314, 2002

23. Champlin R, Schmitz N, Horowitz MM, Chapuis B, Gale RP, Goldman JM, Montserrat E, Ringden O: Blood stem cells compared with bone marrow as a source of hematopoietic cells for allogeneic transplantation. Blood 95: 3702-3709, 2000

24. Blaise D, Attal M, Reiffers J, Michallet M, Bellanger C, Pico JL, Stoppa AM, Payen C, Marit G, Bouabdallah R, Sotto JJ: Randomized study of recombinant interleukin-2 after autologous bone marrow transplantation for acute leukemia in first complete remission. Eur Cytokine Netw 11: 91-98, 2000

25. Bensinger WI, Martin P, Clift RA, Storer B, Forman S, Clift RA, Kashyap A, Negrin RS, Libelly K, Chauncey TR, Storb R, Appelbaum FR: Transplantation of bone marrow as compared with peripheral blood stem cells from HLA identical relatives in patients with hematologic cancers. New Engl J Med 344: 175181,2001

26. Martinez C, Urbano-Ispizua A, Rozman C, Marin P, Rovira M, Sierra J, Montfort N, Carreras E, Montserrat E: Immune reconstitution following allogeneic peripheral blood progenitor cell transplantation: comparison of recipients of positive CD34+ selected grafts with recipients of unmanipulated grafts. Exp Hematol 27: $561-568,1999$

27. Baron F, Beguin Y: Pre-emptive cellular therapy after T-cell depleted allogeneic stem cell transplantation. Biol Blood Marrow Transplant, in press 
28. Powles R, Mehta J, Kulkarni S, Treleaven J, Millar B, Marsden J, Singhal S: Allogeneic blood and bonemarrow stem-cell transplantation in haematological malignant diseases: a randomised trial. Lancet 355 : $1231-1237,2000$

29. Klingemann HG: Cellular therapy of cancer with natural killer cells: will it ever work? J.Hematother.Stem Cell Res. 10: 23-26, 2001

30. Alyea EP: Adoptive immunotherapy: insights from donor lymphocyte infusions. Transfusion 40: 393-395, 2000

31. Horowitz MM, Gale RP, Sondel PM, Goldman JM, Kersey J, Kolb HJ, Rimm, AA, Ringden O, Rozman C, Speck B: Graft-versus-leukemia reactions after bone marrow transplantation. Blood 75: 555-562, 1990

32. Appelbaum FR: Graft versus leukemia (GVL) in the therapy of acute lymphoblastic leukemia (ALL). Leukemia 11 Suppl 4: S15-S17, 1997 


\section{Legends to the figures}

Figure 1. A. Time to 500 neutrophils/ $\mu \mathrm{L}$ after BMT (N=35) or CD34-selected PBSCT $(\mathrm{N}=24)$.

B. Time to 20000 platelets/ $\mu \mathrm{L}$ after BMT $(\mathrm{N}=35)$ or CD34-selected PBSCT $(\mathrm{N}=24)$.

C. Time to $1 \%$ reticulocytes after BMT $(\mathrm{N}=35)$ or CD34-selected PBSCT (N=24).

D. Time to hospital discharge after BMT $(\mathrm{N}=35)$ or CD34-selected PBSCT $(\mathrm{N}=24)$.

Figure 2. A. Cumulative incidence of grade II-IV acute GVHD after BMT (N=35) or CD34selected PBSCT followed by CD8-depleted DLI $(\mathrm{N}=24)$.

B. Cumulative incidence of chronic GVHD after BMT (N=35) or CD34-selected PBSCT followed by CD8-depleted DLI (N=24).

Figure 3. A. Cumulative incidence of relapse after BMT $(\mathrm{N}=35)$ or CD34-selected PBSCT followed by CD8-depleted DLI (N=24).

B. Survival rates of patients grafted with bone marrow $(\mathrm{N}=35)$ or $\mathrm{CD} 34$-selected PBSCT followed by CD8-depleted DLI (N=24). 
Table 1. Characteristics of the two groups of patients

\begin{tabular}{|c|c|c|}
\hline & Study Group & BMT Group \\
\hline No of patients & 24 & 35 \\
\hline \multicolumn{3}{|l|}{ Median age in years (range) } \\
\hline Recipients & $46(14-57)$ & $36(1-56)$ \\
\hline Donors & $40(13-70)$ & $34(3-58)$ \\
\hline Recipient sex (F/M) & $9 / 15$ & $9 / 26$ \\
\hline Donor sex $(F / M)$ & $11 / 13$ & $16 / 19$ \\
\hline \multicolumn{3}{|l|}{ HLA compatibility } \\
\hline Identical & 16 & 30 \\
\hline 1 mismatch & 8 & 5 \\
\hline \multicolumn{3}{|l|}{ Diagnoses } \\
\hline Acute myeloid leukemia & 11 & 17 \\
\hline CR1 & 7 & 12 \\
\hline CR2 & 0 & 1 \\
\hline Relapse & 2 & 3 \\
\hline Refractory & 2 & 1 \\
\hline Acute lymphoid leukemia & 5 & 7 \\
\hline CR1 & 3 & 4 \\
\hline CR2 & 2 & 1 \\
\hline Relapse & 0 & 2 \\
\hline Chronic myeloid leukemia & 3 & 6 \\
\hline $\mathrm{CP} 1$ & 2 & 4 \\
\hline $\mathrm{CP} 2$ & 1 & 0 \\
\hline Blast crisis & 0 & 2 \\
\hline Non-Hodgkin's lymphoma & 3 & 3 \\
\hline CR1 & 1 & 0 \\
\hline CR2 & 2 & 2 \\
\hline Relapse & 0 & 1 \\
\hline Chronic lymphocytic leukemia & 1 & 0 \\
\hline Refractory & 1 & 0 \\
\hline Myelodysplastic syndrome & 1 & 2 \\
\hline Relapse & 0 & 2 \\
\hline Refractory & 1 & 0 \\
\hline \multicolumn{3}{|l|}{ Risk for relapse } \\
\hline Low risk & 12 & 20 \\
\hline High risk & 12 & 15 \\
\hline \multicolumn{3}{|l|}{ Conditioning } \\
\hline With TBI & 19 & 32 \\
\hline Without TBI & 5 & 3 \\
\hline \multicolumn{3}{|l|}{ GVHD prophylaxis } \\
\hline $\mathrm{CyA}+\mathrm{Mtx}$ & 6 & 24 \\
\hline CyA & 18 & 11 \\
\hline G-CSF post-transplant & 24 & 13 \\
\hline
\end{tabular}




\section{Figure 1}

A

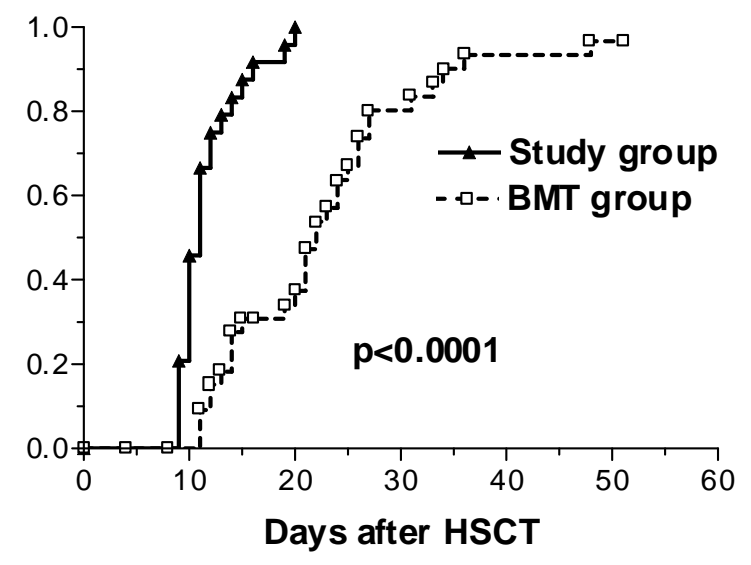

C

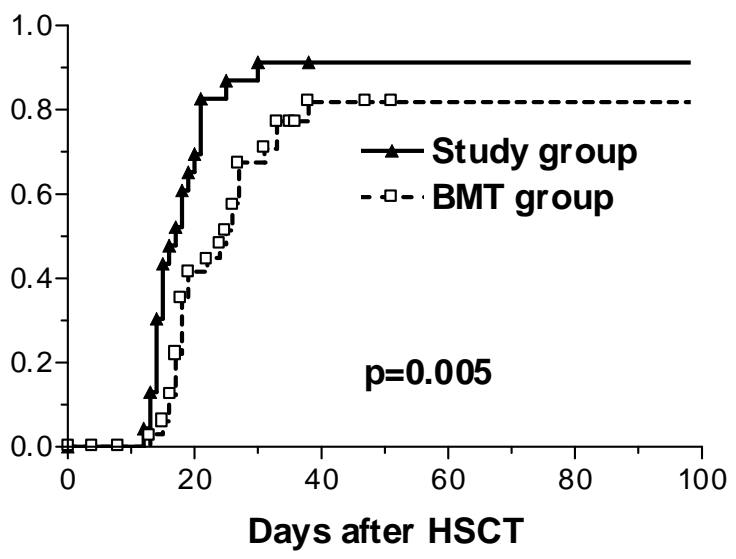

\section{B}

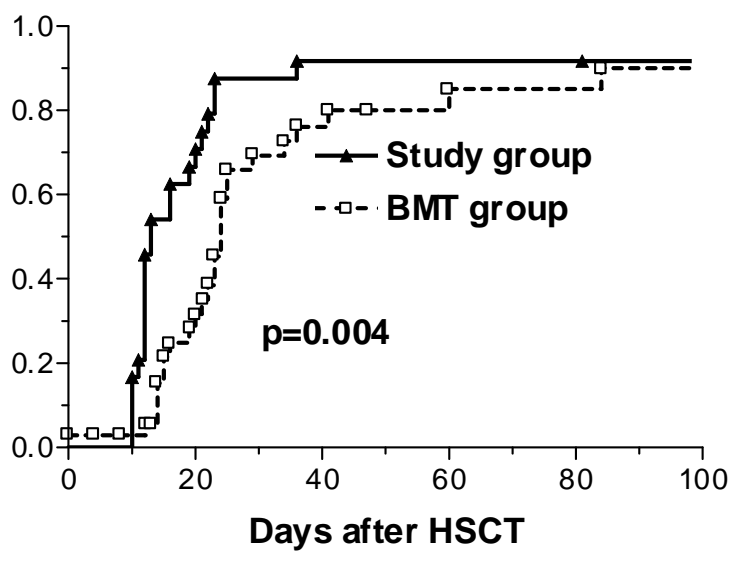

D

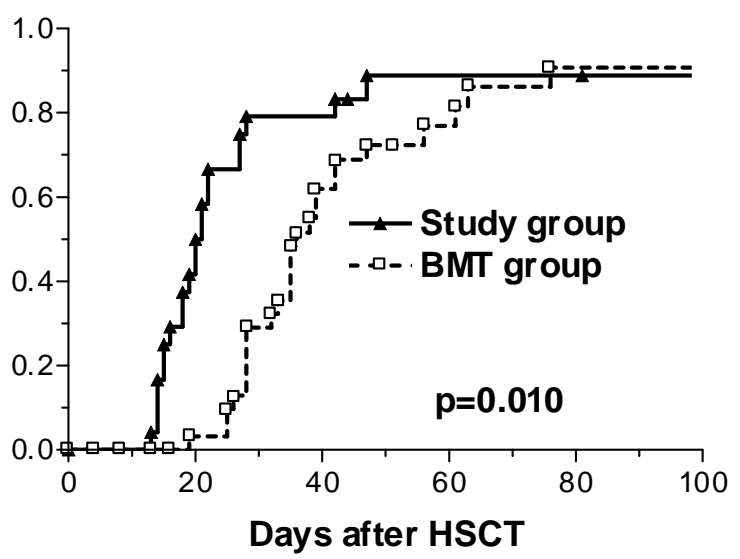




\section{Figure 2}
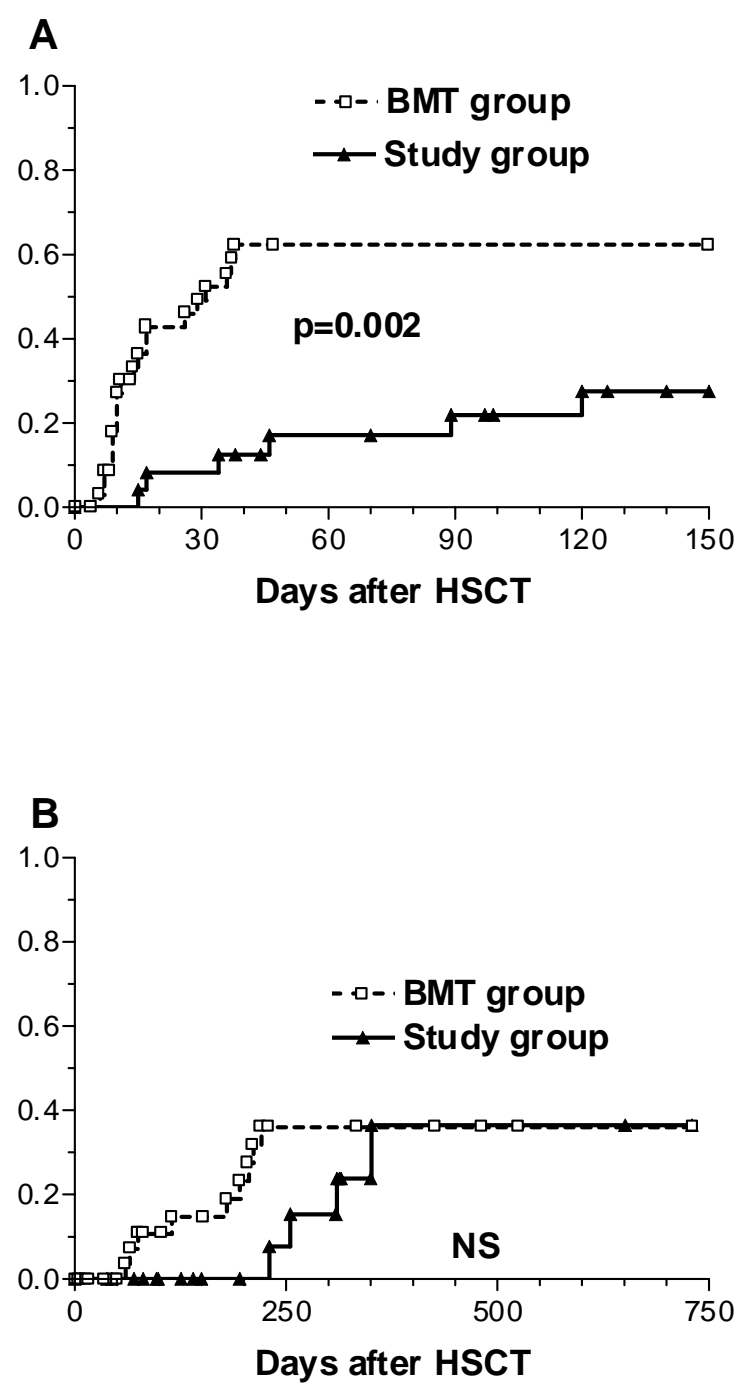
Figure 3

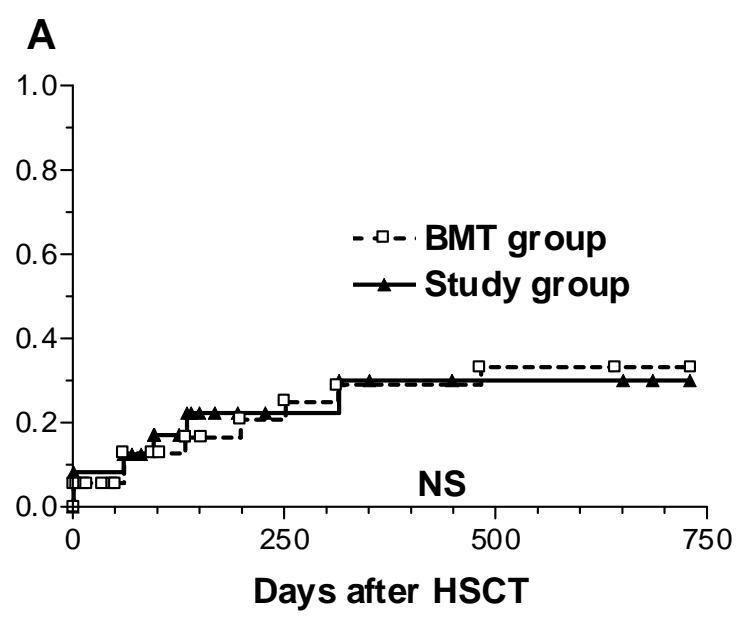

B

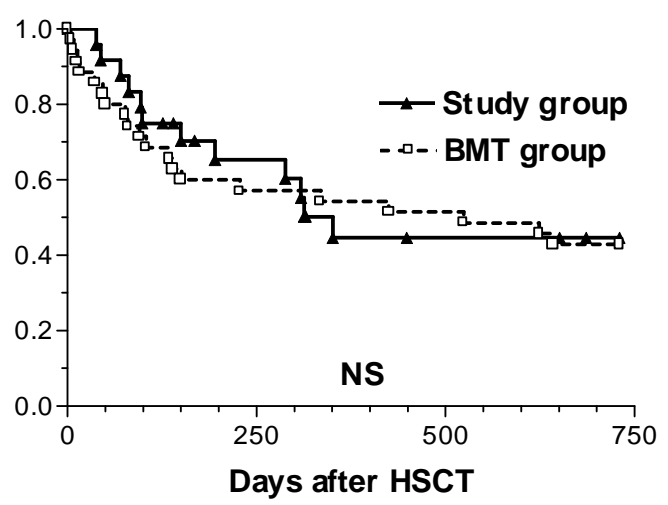


Baron et al., page 21 